\title{
CHALLENGES AND OPPORTUNITIES FOR ENERGY RECOVERY FROM MUNICIPAL SOLID WASTE IN THE RUSSIAN FEDERATION
}

\author{
STEPAN POLYGALOV ${ }^{1}$, GALINA ILINYKH ${ }^{1}$, NATALIA SLIUSAR ${ }^{1}$, \\ VLADIMIR KOROTAEV ${ }^{1}$ \& IRINA RUKAVISHNIKOVA ${ }^{2}$ \\ ${ }^{1}$ Environmental Protection Department, Perm National Research Polytechnic University, Russia \\ ${ }^{2}$ Environmental Economics Department, Ural Federal University, Russia
}

\begin{abstract}
Energy recovery from municipal solid waste (MSW) is currently a key factor in waste management in Russia, as can be seen from the corresponding changes in the state regulatory framework. The paper presents a comparative assessment of different waste flow characteristics; it focuses on pre-treatment options and the method of subsequent thermal treatment. It reflects the basic method of untreated MSW incineration and other advanced technologies which have different levels of waste preparation. Stepby-step research has been carried out in a large Russian city in order to determine different technological approaches to recovering energy from MSW. The study included: 1) field studies of the composition and characterization of MSW; 2) laboratory studies of MSW thermal properties, i.e. moisture, ash content and calorific value; 3 ) several options for waste treatment schemes with equipment of different technical specifications; 4) analysis of material flow, energy flow and key substance flow according to these considered schemes. The research revealed that for all seasons a significant proportion of MSW (almost 40\%) is represented by fines (below $50 \mathrm{~mm}$ ). On average, the energy potential of MSW (the total content of waste paper, polymers, textiles, wood, multilayer packaging, leather, rubber, footwear) amounts to about $40 \%$. It was found that MSW calorific value depends on fraction size, since screening (over $50 \mathrm{~mm}$ ) is characterized by high moisture and low content of valuable components, compared to MSW greater than $50 \mathrm{~mm}$ in size. Pre-processing and treatment of MSW allows solid recovered fuel (SRF) to be obtained with a calorific value similar to brown coal. The energy balance of the process allows the conclusion that $33.8 \%$ of initial MSW energy potential is concentrated in residues from the sorting process, since it has a relatively low calorific value of $4.8 \mathrm{MJ} / \mathrm{kg}$, but a high mass fraction of $47.9 \%$. In the process of MSW treatment and solid fuel production, most of the chlorine and mercury ( $80 \%$ and $55 \%$ respectively) is removed by the rest of the sorting process. The data obtained in the study can be used in selecting the optimal option for energy recovery from MSW.

Keywords: municipal solid waste, energy recovery, solid recovered fuel, calorific value.
\end{abstract}

\section{INTRODUCTION}

MSW includes components with combustible properties which can be used for the industrial production of energy. In many countries of Northern and Western Europe, recovery of energy from MSW ranges from $20 \%$ to $50 \%$ [1]: $53 \%$ in Norway; $51 \%$ in Denmark; $48 \%$ in Switzerland; 55\% in Finland, and 50\% in Sweden. France, Germany and the Netherlands account for more than half of European incineration capacity; the total share of burning MSW in Italy, Sweden and the UK is 74\% [2]; Japan reportedly burns 78\% [1]; and Taiwan and Singapore a similar amount. There are different methods and technologies for energy recovery from MSW, the most common being direct waste combustion without preliminary preparation at waste-to-energy plants (WTE). The alternative solution is MSW treatment on the waste sorting line, where secondary raw materials are separated and solid fuel with high calorific value is produced. This can be used later in various energy-consuming processes, in particular, in cement kilns.

European countries mainly produce solid fuels from waste by mechanical or mechanicalbiological treatment; in this case different processes for waste treatment are used [3]. Papers 
[4]-[7] analyze incoming and outgoing flows in the production of refused derived fuel (RDF) and determine their material, energy and elemental balances.

The authors [8] have obtained high quality RDF by sorting materials from different waste flows in Singapore. They research the thermal properties and elemental composition of various waste components and discuss the suitability of solid fuel produced from MSW. In addition, they identify components with a high heavy metal content. The proximate and ultimate analysis and the calorific value of MSW components determine the quality of a combustible component, e.g. paper and food waste have a high oxygen content; there is a low content of ash and fixed oxygen in PE, PP and PS; PET has a high carbon content, but a low hydrogen value. The chlorine content in PVC is about 55\%. The research has proved that the components PE, PP and PS have the highest combustion values [9].

Several studies have been carried out [10], [11] describing solid fuel values depending on MSW composition and its thermal and chemical values.

There are relatively few examples of MSW thermal treatment plants in the RF. At the JSC "Autopark No. 1 Spetstrans", St. Petersburg, SRF with the lowest calorific value of 15.9$20.3 \mathrm{MJ} / \mathrm{kg}$ is produced and it is used at a cement plant [12]. In Moscow, there are three waste incineration plants (WTE) which generate electricity; their power is relatively small (3.6-12 MW). The WTE plants in Vladivostok, Murmansk, Pyatigorsk, and Cherepovets produce thermal energy [13].

The literature review shows that in Russia there is almost no scientific research on MSW thermal properties which can be used to estimate the energy values of various waste flows obtained in the production of SRF from MSW. The authors of the article [14] investigate the methods of solid municipal waste separation in the production of solid fuel for the cement industry. They identify MSW components to be removed during the production of fuel. The article [15] looks into possible ways of using SRF in industrial furnaces for various manufactures, which are mainly run on traditional types of SRF. The assessment of MSW energy potential on stages of waste management and the assessment of thermal properties of MSW components are carried out in the city of Perm [16].

Recently, public authorities, industry and business in Russia have shown great interest in energy recovery from MSW treatment. The use of waste energy potential can solve the urgent problem of the transition from waste disposal at landfills to waste energy recovery. In this regard, the Russian Federation State Program "Energy Efficiency and Energy Development" was approved by RF Government Decree \# 321 of April 15, 2014 (issued on March 30, 2013); the program includes the subprogram "Development of renewable energy sources". One of these renewable energy sources is MSW as fuel. At the end of February 2017, the Government of the Russian Federation passed a decree regulating the competitive selection and implementation of energy recovery from MSW projects. Similar to renewable energy projects, these are supported by the government through contracts in the electricity and power market. Energy production from MSW is one of the priorities in waste management; this can be seen in changes in the regulatory and legal framework of Russia, in particular in the latest development of the Federal Law on waste management. Several Federal State Standards for SRF and RDF production have been developed, specifying that the main parameters reflecting the qualitative characteristics of fuel are a lower calorific value and a content of chlorine and mercury. However, the existing waste management system in the Russian Federation presents obstacles in meeting the standards without MSW pre-treatment.

Methods and technologies for increasing MSW calorific value could include: extraction of poorly combustible components (food waste, glass, fines, etc.) using mechanical and sensor-based sorting methods; addition of high calorific value components (for example, other waste with higher calorific value); and decreasing moisture by drying. 
The disadvantage of the first approach is a significant reduction in waste mass that is subject to energy recycling, and the emergence of undesirable flows that require other methods of utilization. The second method is theoretically feasible, but in practice it might be difficult to choose economically expedient high-calorific flow of materials that can be disposed of together with poorly combustible waste. Drying of waste is advisable only in cases where excess heat is applicable for other processes.

In choosing the most effective method of MSW treatment, it is recommended to take into account the energy (heat and technical) properties of waste and to justify the efficiency of proposed technologies from both points of view: required investment and the ecological effect, adjusted for the quantity and quality of disposed waste and for equipment efficiency.

\section{METHODS AND MATERIALS}

Evaluation of the proposed technologies for energy recovery for MSW has been carried out step by step with a specific reference to a large city in Russia and includes the following stages:

- field studies of MSW components and fractional composition;

- laboratory studies of MSW thermal properties: moisture, ash content and calorific value;

- $\quad$ several waste treatment schemes have been proposed with allowance for operational efficiency of equipment;

- analysis of material, energy and key substances flows according to the proposed scheme.

\subsection{Investigations of MSW component and fractional composition}

The methodology assessing MSW energy potential has been developed [17], [18], which includes detailed field studies of waste fractional and component composition, as well as laboratory studies of moisture and ash content of individual components. The accuracy and reliability of the results has been ensured by experimental studies of MSW components and fractional composition conducted in each season (spring, summer, autumn, winter) over 7 days, with a daily sampling and analysis of 5 samples. A sample weight amounted to $100 \pm$ $20 \mathrm{~kg}$, depending on the objectives of the studies.

To determine MSW fractional composition, several sizes of sieves were used: 250, 100, $50,15 \mathrm{~mm}$. A total list of identified components included 41 names. The studies of MSW composition included a category "water" found in bottles, jars and containers, as its evaporation consumes heat and thereby reduces the total calorific value of MSW.

\subsection{Laboratory studies of MSW thermal properties}

Moisture and ash content sampling were carried out in accordance with GOST 33626-2015 "Solid fuel from household waste. Sampling methods" (EN 15442: 2011). Laboratory studies of moisture content in MSW components were carried out in accordance with the requirements of GOST 33512.3-2015 "Solid fuel from household waste. Moisture specification by drying. Part 3. Analytical moisture" (EN 15414-3: 2011). Ash content of MSW components was calculated according to GOST 33511-2015 "Solid fuel from household waste. Specification of ash content" (EN 15403: 2011).

To calculate MSW net calorific value, the following formula is used [19]:

$$
Q_{i}^{r}=\sum\left[K_{n}^{r}\left(1-W_{t n}^{r} / 100\right)\left(1-A_{n}^{d} / 100\right) \times Q_{i n}^{d a f}\right]-0.02442 \times \sum\left(K_{n}^{r} \times W_{t n}^{r}\right),
$$


where:

$Q_{i}^{r} \quad=$ calorific value of MSW, $\mathrm{MJ} / \mathrm{kg}$;

$K_{n}^{r} \quad=$ mass fraction of a component, $\%$;

$W_{t n}^{r}=$ moisture content of a component, \%;

$A_{n}^{d} \quad=$ ash content of a dry mass, $\%$;

$Q_{\text {in }}^{\text {daf }}=$ net calorific value of a dry ashless mass, $\mathrm{MJ} / \mathrm{kg}$.

\subsection{MSW treatment options}

The paper focuses on the most common MSW treatment options which include MSW preparation and thermal treatment to generate heat and electric energy or to produce solid fuel from waste. Energy recovery from waste is carried out at incineration plants either by direct incineration of waste without pre-treatment, or by burning rests from sorting plants. Solid fuel from waste with a high energy value is also obtained on waste sorting lines by extracting secondary raw materials for their subsequent use in energy-consuming technological processes, e.g. in cement kilns. It is theoretically possible to increase the calorific value of separated thermally recoverable fractions by adding sub-standard secondary raw materials and combustible wastes, such as oil production and oil refinery waste or wood waste. The study does not focus on this method since it is rarely feasible.

The main objective of the current study is to conduct a comparative evaluation of waste flows focusing on the methods of pre-treatment and further thermal treatment. In this regard, the considered options include a basic method of untreated MSW incineration and some advanced methods with different levels of waste pre-treatment.

\subsection{Analysis of material, energy and elemental flows}

Material, energy and elemental balances of different options for MSW treatment and disposal are based on material flow analysis methodology [20]. The results are presented in STAN 2.5.1302 and Sankey diagrams. The chlorine and mercury elemental balance was calculated based on dry weight concentrations of these substances in individual components [7], [21], [22] and the composition of each flow.

\section{RESULTS AND DISCUSSION}

\subsection{Component and fractional composition of MSW}

The current research of MSW composition throughout the seasons presents an average annual calculation of MSW fractional composition and its component composition by 13 categories of components, as well as moisture value (W), ash content of individual components to dry matter $(\mathrm{Ad})$ and their calorific value $(\mathrm{CV})$ to dry ashless mass $\left(\mathrm{Q}^{\text {daf }}\right)$ (Table 1). A significant part of MSW (almost $40 \%)$ is represented by fine fraction $(<50 \mathrm{~mm})$ with high moisture value and low content of valuable components. A major part of MSW composition comprises food waste, screenings, polymers and waste paper. On the basis of MSW component composition calculation, it can be concluded that MSW energy potential (the total content of waste paper, polymers, textiles, wood, multilayer packaging, leather, rubber, footwear) averages at about $40 \%$. 
Table 1: Composition and thermal properties of individual components.

\begin{tabular}{|c|c|c|c|c|c|c|c|c|}
\hline \multirow[t]{2}{*}{ Name } & \multicolumn{5}{|c|}{ Composition } & \multirow[t]{2}{*}{$\mathrm{W}, \%$} & \multirow[t]{2}{*}{$\mathrm{A}^{\mathrm{d}}, \%$} & \multirow{2}{*}{$\begin{array}{l}\mathrm{Q}^{\text {daf }} \\
\mathrm{MJ} / \mathrm{kg}\end{array}$} \\
\hline & \begin{tabular}{|l|}
$>250$ \\
$\mathrm{~mm}$ \\
\end{tabular} & \begin{tabular}{|l|}
$100-250$ \\
$\mathrm{~mm}$
\end{tabular} & $\begin{array}{l}50-100 \\
\mathrm{~mm}\end{array}$ & \begin{tabular}{|l|}
$<50$ \\
$\mathrm{~mm}$ \\
\end{tabular} & Total & & & \\
\hline $\begin{array}{l}\text { Organic } \\
\text { waste }\end{array}$ & 0.34 & 7.69 & 5.18 & 10.42 & 23.63 & $72.1-81.1$ & $15.0-22,8$ & 18.3 \\
\hline $\begin{array}{l}\text { Waste } \\
\text { paper }\end{array}$ & 1.58 & 4.53 & 2.26 & 2.94 & 11.31 & $30.0-41.0$ & $12.9-17.1$ & 16.9 \\
\hline Polymers & 0.66 & 10.17 & 4.10 & 1.75 & 16.69 & $24.2-27.0$ & $3.8-9.9$ & 34.5 \\
\hline Glass & 0.00 & 5.83 & 1.42 & 0,39 & 7.64 & 3.5 & 100.0 & 0.0 \\
\hline Metal & 0.12 & 0.89 & 0.36 & 0.03 & 1.40 & 3.5 & 100.0 & 0.0 \\
\hline Textile & 0.86 & 1.52 & 0.51 & 0.04 & 2.92 & $11.5-37.9$ & $2.7-9.3$ & 22.6 \\
\hline Wood & 0.47 & 0.46 & 0.13 & 0.02 & 1.08 & $10.5-24.3$ & $3.0-8.5$ & 18.9 \\
\hline $\begin{array}{l}\text { Complex } \\
\text { products }\end{array}$ & 0.32 & 0.94 & 0.40 & 0.00 & 1.67 & $9.7-13.6$ & $28.8-36.6$ & 24.3 \\
\hline $\begin{array}{l}\text { Hazardous } \\
\text { substances }\end{array}$ & 0.00 & 0.28 & 0.14 & 0.03 & 0.45 & 3.5 & 50.0 & 20.1 \\
\hline Inerts & 1.36 & 1.20 & 0.75 & 1.64 & 4.95 & $4.1-8.2$ & 100.0 & 0.0 \\
\hline Other & 0.33 & 4.28 & 1.66 & 2.85 & 9.11 & $31.0-40.2$ & $20.5-34.6$ & 22.3 \\
\hline Fines & 0.00 & 0.00 & 0.00 & 18.69 & 18.69 & $45.4-65.3$ & $50.1-63.9$ & 20.1 \\
\hline $\begin{array}{l}\text { Additional } \\
\text { (water) }\end{array}$ & 0.14 & 0.26 & 0.05 & 0.00 & 0.45 & 100 & 0.0 & 0.0 \\
\hline TOTAL & 6.18 & 38.04 & 16.97 & 38.81 & 100 & & & \\
\hline
\end{tabular}

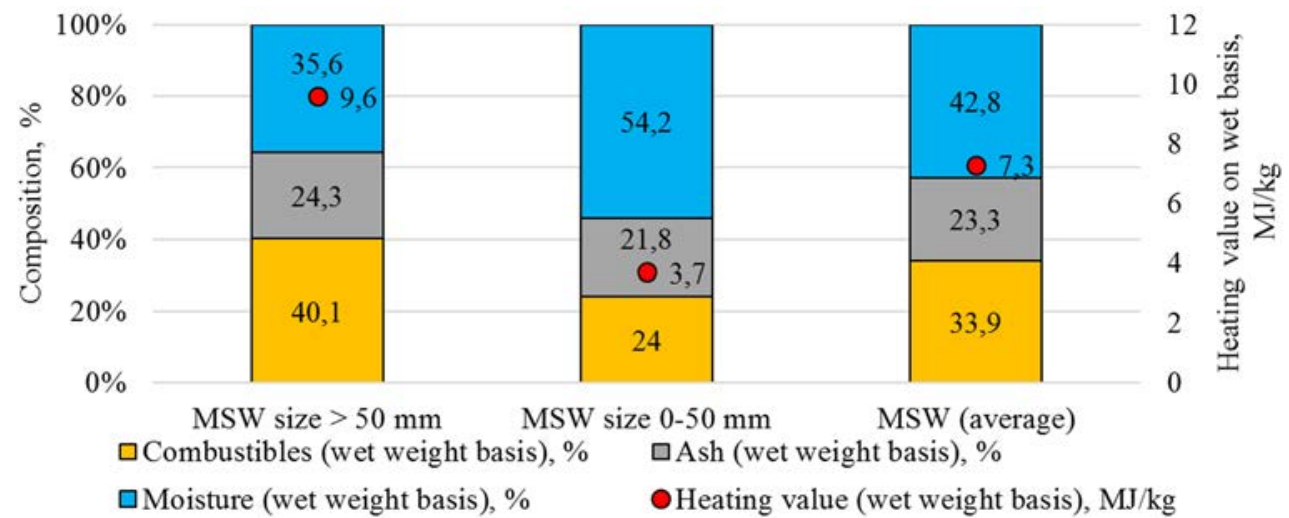

Figure 1: Thermal properties of MSW by fractions.

\subsection{Thermal properties of MSW}

Studies of the humidity and ash content of MSW different fractions and data on the calorific value of individual components allows for a separate calculation of calorific value for MSW 
fractions $>50 \mathrm{~mm}$, fractions $<50 \mathrm{~mm}$ and for MSW as a whole. The thermal properties of MSW fractions of different sizes are presented in Fig. 1.

\subsection{MSW thermal treatment options}

The choice of a thermal treatment scenario has been based on the following considerations:

- The current system of MSW treatment. In Russia, the system of separate waste collection is poorly developed, though attempts have been made to implement it in some cities. However, the process is complex and lengthy, and requires major changes in the waste management system. So, all options are built on the premise that a separate waste collection system does not exist or is ineffective, as if the proposed technologies are to be introduced in the shortest possible time.

- The MSW energy recovery system, supported by regulatory legal acts. Currently, two options are considered at the legislative level: direct incineration and SRF and RDF production and consumption.

- The existing market in MSW treatment equipment and technologies.

- Studies of MSW composition and thermal properties, e.g. dependency of moisture and ash content of individual components and MSW energy value on the size of a fraction. Due to the lack of separate waste collection, MSW contains a significant proportion of organic components - food residues and plant waste, whose high moisture value affects the overall waste moisture value and, correspondingly, low heat value which is often insufficient to support self-burning of waste or required efficiency in a process [23].

Taking into account the highlighted aspects, several possible scenarios for waste pretreatment and thermal treatment have been considered:

- Scenario 0. Direct incineration of untreated waste (S.0). It is carried out at waste-toenergy plants with generation of heat and electric energy. All waste coming to plants is incinerated without any pre-treatment.

- Scenario 1. Incineration of rests of MSW sorting (S.1). The aim is to separate fine fraction from MSW and dispose of it. The rests are sent for further incineration.

- Scenario 2. Energy recovery from MSW (S.2). Compared to the previous scenario, rests from the sorting plant are processed (sensor-based sorting) with the release of burning components. The separated thermally recoverable fractions already correspond to solid fuel from waste (by heat value, chlorine and mercury content), but do not meet the requirements of consumers, e.g. cement producers, in moisture value and particle size.

- Scenario 3. Solid fuel from waste (S.3). This option complements the previous one with necessary pre-treatment technologies to meet the requirements of customers, e.g. cement plants [24]. Shredding and drying are added to the process.

MSW pre-treatment and energy recovery technology is successive for all 4 scenarios. It is presented as a general scheme of material flows (Fig. 2), where each follow-up option is added to the previous one.

The MSW treatment and energy recovery process consists of the following operations:

- Screening (a cell size is $50 \mathrm{~mm}$ ) is designed to sort out fines. Screening is an important stage in MSW preparation and treatment; the moisture value of fine 
screenings $<50 \mathrm{~mm}$ is higher than of those $>50 \mathrm{~mm}$ (Fig. 1). Fine fraction separation increases MSW calorific value.

- Separation of secondary raw materials: cardboard, office paper and newspapers, polyethylene (PE) film, PET and PE bottles, glass, ferrous and non-ferrous metals.

- The efficiency of the MSW sorting process is calculated based on operated waste sorting facilities.

- Selection of thermally recoverable fractions, aimed at the release of combustible components (waste paper and polymers), on condition that sorting efficiency is $95 \%$. PVC components are removed from fuel to meet chlorine requirements in SRF.

- $\quad$ SRF is treated by shredding and drying separated thermally recoverable fractions. At this stage fuel is treated to meet consumers' quality requirements.

\subsection{Evaluation of material, energy and elemental flows}

The total material balance of the technological process of MSW preparation and energy recovery is calculated for a 100,000-tonne process. Fig. 2 presents the material balance of the process and shows that the distribution of components for the considered options affects the calorific value of a specific MSW flow:

- in Scenario 0, all $100 \%$ of MSW with a lower heating value of $7.3 \mathrm{MJ} / \mathrm{kg}$ can be sent to WTE plants;

- in Scenario 1, the rests of sorting process (62\% of MSW initial mass) with a lower heating value of $7.7 \mathrm{MJ} / \mathrm{kg}$ can be sent to WTE plants

- in Scenario 2, thermally recoverable fractions (14.2\% of MSW initial mass) with a heating value of $17.8 \mathrm{MJ} / \mathrm{kg}$ are extracted from the rests of the sorting process;

- in Scenario 3, solid fuel after drying has a heating value of $22.0 \mathrm{MJ} / \mathrm{kg}$ and accounts for $11.7 \%$ of MSW initial mass.

In scenarios S.1-S.3, incoming MSW flow generates about 11\% (by mass) of secondary raw materials for further recycling and $27 \%$ of fines are sent to waste disposal sites. Scenarios S. 2 and S. 3 produce $48 \%$ of sorting residues, which are also sent to MSW landfills. The initial moisture value of separated thermally recoverable fractions (S.2) accounts for $25.6 \%$; after drying and crushing, it is possible to obtain $11.7 \%$ of SRF with a moisture value of $10 \%$. Loss of moisture at drying (S.3) amounts for $2.46 \%$.

At the secondary raw materials stage, components with energy potential are selected, e.g. corrugated cardboard, office paper and newspapers, PE film, PET and PE bottles. In different technological processes combustible components may be extracted as thermally recoverable fractions to increase the mass fraction of waste-to-solid fuel and to increase its calorific value. Fuel quality composition is assessed by moisture value, ash content and chemical elements values: carbon, hydrogen, oxygen, nitrogen and sulphur. The presence of moisture in MSW reduces the number of combustible elements, and because heat is used to evaporate moisture during combustion, the moisture content of the waste impacts its heating value. Ash content reduces calorific value and considerably complicates the combustion process and furnace operation. Calorific value is largely determined by the content of "combustible" elements in waste: carbon, hydrogen and sulphur. Combustible elements are bound with non-combustible elements - oxygen and nitrogen - which form an internal ballast in MSW components. Table 2 compares the elemental composition and main thermal properties of waste flows for all scenarios against some fossil fuels. Table 2 shows that the content of combustible elements in the working mass is 2.4 times higher in prepared fuel than in initial MSW. Moreover, the 


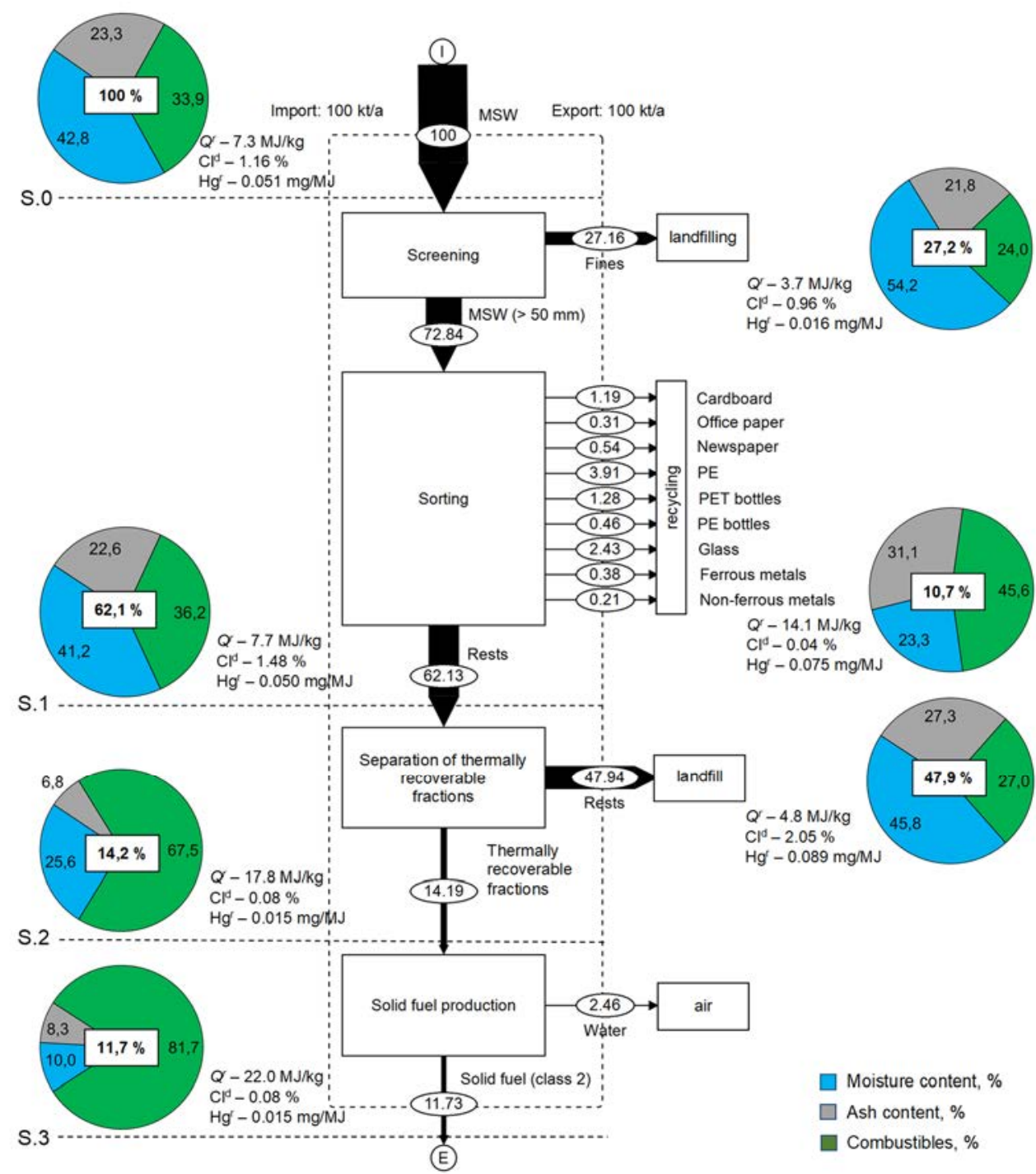

Figure 2: Material balance of MSW treatment and energy recovery.

quality of combustible fraction slightly improves as the content of calorific carbon increases and the content of ballast oxygen decreases. Thus, solid fuel from MSW is comparable to brown coal in the balance of elements.

Summarising the results, the energy balance and elemental balance for chlorine and mercury in the production of solid fuel from MSW were calculated. Fig. 3(a) presents the material balance of pre-treatment and energy recovery from MSW. The energy balance of MSW initial flow was calculated in relation to the calorific value and mass fraction of each output (Fig. 3(b)). 
Sorting residues take about one-third of the energy potential of initial MSW flow, which is comparable to the energy potential of SRF. This is because sorting residues which have a relatively low calorific value of $4.8 \mathrm{MJ} / \mathrm{kg}$ surpass solid fuel more than three times in mass. Solid fuel flow has a high calorific value at a relatively small mass.

Table 2: The elemental composition and main thermal properties of waste flows for all scenarios compared to some fossil fuels.

\begin{tabular}{|l|l|l|l|l|l|l|l|l|l|l|}
\hline Flow & $\begin{array}{l}\text { Mois- } \\
\text { ture, } \%\end{array}$ & $\begin{array}{l}\text { Ash } \\
\text { content, } \\
\%\end{array}$ & $\begin{array}{l}\text { Com- } \\
\text { bustible } \\
\text { mass, } \%\end{array}$ & \multicolumn{2}{l}{$\begin{array}{l}\text { Elemental composition } \\
\text { (on fuel mass) } \%\end{array}$} & \multicolumn{1}{l}{$\begin{array}{l}\text { CV } \\
\text { MJ/kg }\end{array}$} \\
\hline \multicolumn{7}{|l|}{} \\
\end{tabular}

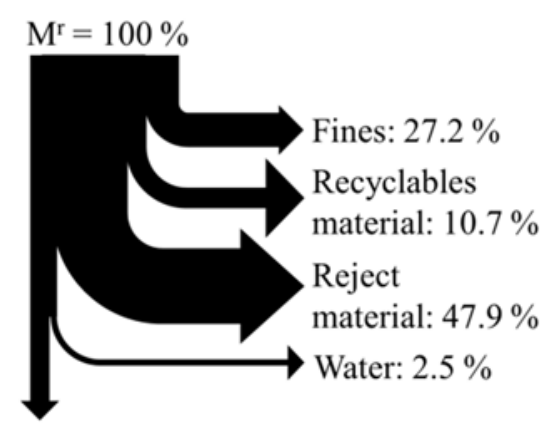

SRF: $11.7 \%$

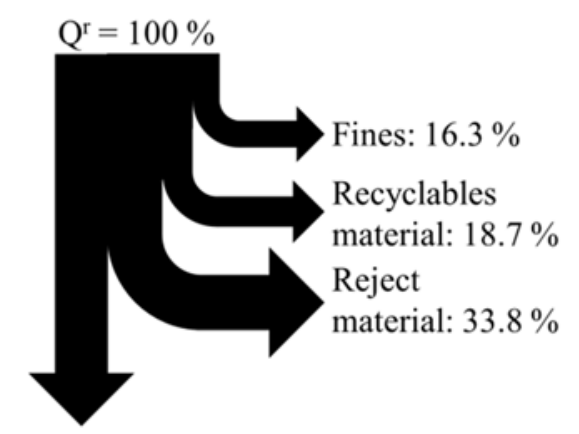

SRF: $31.2 \%$

Figure 3: (a) Material; (b) and energy balances in a technological process. 


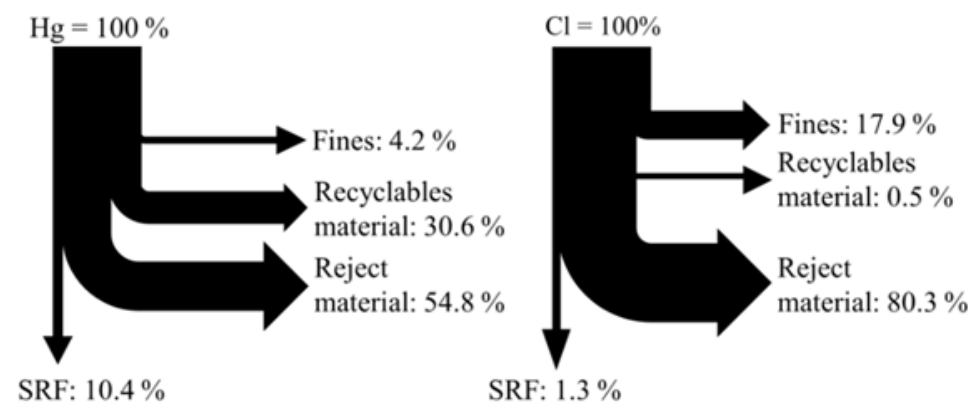

Figure 4: (a) The elemental balance for chlorine; and (b) Mercury.

The elemental balance for chlorine and mercury in original MSW flow was calculated with respect to the chlorine and mercury content of individual components, the component composition of individual flows and the mass fraction of each output (Fig. 4) [7], [21], [22].

In MSW treatment and SRF and RDF production most of the chlorine is removed to sorting residues, since chlorine is predominantly present in $\mathrm{PVC}$, which is removed by sensor-based sorting. Food waste and PVC components contribute most to fines from the sorting process, where the concentration of food waste with insignificant chlorine is high, while the presence of PVC with high chlorine is low. Chlorine content in food waste can be accounted for by the presence of salt in food [7].

Mercury concentrates mainly in sorting residues and accounts for approximately $55 \%$; the greatest contribution is made by textiles and ferrous metals [7], [22]. In the flow of secondary materials, the bulk of mercury content comes from metals (total contribution to secondary raw materials is about 78\%). The content of chlorine and mercury in solid fuels from waste (S.3) meets the requirements of GOST 33516-2015 (EN 15359: 2011). Thus, selecting technologies for MSW treatment it is possible to control the flow of waste and its thermal properties, taking into account the technological characteristics of the energy recovery equipment.

\section{CONCLUSIONS}

Unlike many countries, in Russia the system of separate waste collection is not actually applied; research proves that there are many organic components - food and plant residues, in waste. The high humidity of these components affects the overall high humidity and relatively low calorific value accordingly. Glass as a secondary resource is not in demand, so all consumed glass is found in waste flows, again reducing overall calorific value. Cardboard, which could increase the combustible properties of waste, is in high demand in Russia as it is recycled material, so it is intensively recovered at all stages of waste treatment. Therefore, mixed MSW usually has a low calorific value which is often insufficient to maintain selfcombustion or ensure the necessary efficiency of a process.

MSW has energy potential that can be controlled by selecting different treatment technologies and achieving the required calorific value of a target flow (SRF), with reference to the component composition of original MSW and its thermal properties. The latest reliable experimental data on waste energy properties highlights the potential of thermal methods of waste recovery. Laboratory studies of moisture and ash content in individual components of different MSW fractions reveal the change in MSW calorific value depending on fraction size: larger fractions have lower humidity, higher combustible mass and, correspondingly, higher calorific value. 
The energy balance of a process depends on combustible components (waste paper, polymers) and their treatment: the more components are recovered as secondary raw materials, the less calorific sorting residues will be, resulting in a smaller amount of solid fuel generated. The calorific value of initial MSW flow is rather low $(7.3 \mathrm{MJ} / \mathrm{kg})$, which may present certain technological difficulties, but the combustion of MSW without preliminary treatment allows to minimize land disposal (only ash received after burning is sent to landfill). Preliminary waste sorting with separation of secondary raw materials increases the calorific value of rests from the sorting process to initial MSW flow values; however, its flow mass accounts for only $62 \%$ and it generates a flow of fine fraction that must be disposed of in landfill. When thermally recoverable fractions (S.2) are sorted from the rests, their calorific value $(17.8 \mathrm{MJ} / \mathrm{kg})$ is much higher than the calorific value of initial MSW, but this fraction averages to only $14.2 \%$ of initial MSW mass and it boosts the amount of waste sent to MSW landfill (75\%). To meet the requirements for SRD and RDF, it is advisable to introduce a stage of additional preparation of thermally recoverable fractions, in particular, shredding and drying, which enables calorific value to increase to $22.0 \mathrm{MJ} / \mathrm{kg}$. Comparative evaluation of different waste flow properties has revealed that the choice of MSW energy recovery scenario should be based on MSW composition and its thermal properties. In contrast to MSW incineration, the generation of high-calorie fuel from MSW requires significant waste treatment, reduces energy-recyclable waste mass and produces "undesirable" energy recycling flows which can be disposed of in landfill.

\section{ACKNOWLEDGEMENT}

The work was supported by Act 211 Government of the Russian Federation, contract № 02.A 03.21.0006.

\section{REFERENCES}

[1] Энергетическая утилизация твердых бытовых отходов. Энергетический бюллетень: 48. (2017). Аналитический центр при правительстве Российской Федерации. Online. http://ac.gov.ru/files/publication/a/13175.pdf. Accessed on: 8 Apr 2018. (In Russian)

[2] «Энергия из отходов». Online. https://w2e.ru/news/belyy-dym-iz-truby-chtovmeste-s-parom-vybrosit-v-vozdukh-msz-v-osinovo. Accessed on: 4 Apr 2018. (In Russian)

[3] Velis, C. et al., Solid recovered fuel: Materials flow analysis and fuel property development during the mechanical processing of biodried waste. Environmental Science \& Technology, 47(6), pp. 2957-2965, 2013. DOI: 10.1021/es3021815.

[4] Rada, E.C. \& Ragazzi, M., Selective collection as a pretreatment for indirect solid recovered fuel generation. Waste Management, 34(2), pp. 291-297, 2014. DOI: 10.1016/j.wasman.2013.11.013.

[5] Zaccariello, L., Cremiato, R. \& Mastellone, M.L., Evaluation of municipal solid waste management performance by material flow analysis: Theoretical approach and case study. Waste Management \& Research, 33(10), pp 871-885, 2015. DOI: $10.1177 / 0734242 \times 15595284$.

[6] Nasrullah, M., Vainikka, P., Hannula, J., Hurme, M. \& Karki, J., Mass, energy and material balances of SRF production process. Part 3: Solid recovered fuel produced from municipal solid waste. Waste Management \& Research, 33(2), pp. 146-156, 2015. DOI: $10.1177 / 0734242 \times 14563375$.

[7] Nasrullah, M., Vainikka, P., Hannula, J., Hurme, M. \& Oinas, P. Elemental balance of SRF production process: solid recovered fuel produced from municipal solid waste. 
Waste Management \& Research, 34(1) pp. 38-46, 2016. DOI: $10.1177 / 0734242 \times 15615697$.

[8] Zhao, L. et al., Characterization of Singapore RDF resources and analysis of their heating value. Sustainable Environment Research, 26(1), pp. 51-54, 2016. DOI: 10.1016/j.serj.2015.09.003.

[9] Zhou, H., Meng, A., Long, Y., Li Q. \& Zhang, Y., Classification and comparison of municipal solid waste based on thermochemical characteristics. Journal of the Air \& Waste Management Association, 64(5), pp. 597-616, 2014. DOI: 10.1080/10962247.2013.873094.

[10] Rotter, V.S., Kost, Th., Winkler, J. \& Bilitewski, B., Material flow analysis of RDFproduction processes. Waste Management, 24(10), pp. 1005-1021, 2004. DOI: 10.1016/j.wasman.2004.07.015.

[11] Ranieri, E., Ionescu, G., Fedele, A., Palmieri, E., Ranieri, A.C. \& Campanaro, V., Sampling, characterisation and processing of solid recovered fuel production from municipal solid waste: An Italian plant case study. Waste Management \& Research, 35(8), pp. 890-898, 2017. DOI: 10.1177/0734242x17716276.

[12] Bushhinin, V.V., Lomtev, A.Yu., Budko, A.G. \& Pakhtinov, V.M., Альтернативное топливо из твердых бытовых отходов. Твердые бытовые отходы, 4, pp. 38-41, 2015 (in Russian).

[13] ИТС 9-2015, Информационно-технический справочник по наилучшим доступным технологиям. Обезвреживание отходов термическим способом (сжигание отходов). Бюро НДТ, 2015. (In Russian)

[14] Vaysberg, L.A., Mikhailova, N.V. \& Gerasimov, A.M., Топливо для цементной промышленности из твердых коммунальных отходов. Химия твердого топлива, 1, pp. 62-70, 2017 (in Russian).

[15] Bazyleva, Ya.V., Перспективы производства вторичного топлива из отходов. Твердые бытовые отходы, 11, pp. 24-27, 2015 (in Russian).

[16] Krivoshein, V.G., Оценка энергетического потенциала ТБО на примере г. Перми. Экология и промышленность России, 1, pp. 45-47, 2009 (in Russian).

[17] Ilyinikh, G.V., Slyusar, N.N. \& Korotaev. VN., Морфологический состав отходов: основные тенденции изменения. Твердые бытовые отходы, 8, pp. 38-41, 2011 (in Russian).

[18] Polygalov, S.V., Ilinykh, G.V. \& Korotaev, V.N., Зависимость теплотехнических свойств твердых коммунальных отходов от компонентного и фракционного состава. Теоретическая и прикладная экология, 2, pp. 70-78, 2018 (in Russian).

[19] Tugov, A.N., Исследование процессов и технологий энергетической утилизации бытовых отходов для разработки отечественной ТЭС на ТБО. Автореф. дис. ...док. техн. наук, Москва: НИУ МЭИ, 2012 (in Russian).

[20] Brunner, P.H. \& Rechberger, H., Practical Handbook of Material flow Analysis, CRC Press LLC, 2004.

[21] Lederer, J. et al., Description Of The Environmental Pressures For Each Relevant Combination Of Material And Recycling/Treatment Technology, Vienna University of Technology_-Institute for Water Quality and Waste Management IWA: Austria, p. 176, 2009.

[22] Walter, RN., Combustion and Incineration Processes, Marcel Dekker, Inc., 2002.

[23] Komilis, D., Kissas, K. \& Symeonidis, A., Effect of organic matter and moisture on the calorific value of solid wastes: An update of the Tanner diagram. Waste Management, 34(2), pp. 249-255, 2014. DOI: 10.1016/j.wasman.2013.09.023. 
[24] Lederer, J., Trinkel, V. \& Fellner, J., Wide-scale utilization of MSWI fly ashes in cement production and its impact on average heavy metal contents in cements: The case of Austria. Waste Management, 60, pp. 247-258, 2017. DOI: 10.1016/j.wasman.2016.10.022.

[25] Belousov, V.N., Smirnova, O.S. \& Smorodin, S.N., Топливо и теория горения. СПб: ВШТЭ СПбГУПТД, 2016 (in Russian). 